\title{
Short-Term Toxicity and Reproduction Studies in Rats with Hexachloro-(1,3)-butadiene
}

\author{
Johannes H. Harleman ${ }^{1}$ and Willem Seinen ${ }^{2}$ \\ Working Group Pathology-Toxicology, Departments of Pathology and Pharmacology-Toxicology, \\ Faculty of Veterinary Sciences, University of Utrecht, Bilstraat 172, Utrecht, The Netherlands
}

Received September 28, 1977; accepted July 5, 1978

\begin{abstract}
Short-Term Toxicity and Reproduction Studies in Rats with Hexachloro-(1,3)-butadiene. Harleman, J. H., and Seinen, W. (1979). Toxicol. Appl. Pharmacol. 47, 1-14. In rats given daily doses of $0.0 .4,1.0,2.5,6.3$, and $15.6 \mathrm{mg}$ of hexachloro-(1,3)-butadiene (HCBD) $/ \mathrm{kg}$ by gavage for 13 weeks, no effect levels of 1.0 and $2.5 \mathrm{mg} / \mathrm{kg}$ were established for females and males, respectively. Inhibition of growth occurred in both sexes at the two highest doses and degeneration of proximal renal tubules occurred at doses of 2.5 and $6.3 \mathrm{mg} / \mathrm{kg}$ or more in females and males, respectively. Urine-concentrating ability was significantly reduced in females at doses of $2.5 \mathrm{mg} / \mathrm{kg}$ or more and in males at $15 \mathrm{mg} / \mathrm{kg}$. Relative kidney weights were increased at the two highest doses in both sexes. Increased cytoplasmic basophilia of hepatocytes occurred in males at the two highest doses, associated with an increase in liver weight. In females, liver weights were increased only at the $15.6 \mathrm{mg} / \mathrm{kg}$ dose. In other studies, nephrotoxicity was noted after 2 weeks of administration of 150 and $450 \mathrm{ppm}$ in the diet, characterized by epithelial hyperplasia of the proximal renal tubules. Ataxia associated with demyelination and fragmentation of femoral nerve fibers also occurred at a dietary lcvel of $1500 \mathrm{ppm}$. Except for dccreased body wcights at birth and weaning, no effects on fertility or progeny were found. No porphyrinogenic effects were noted.
\end{abstract}

Hexachloro-(1,3)-butadiene (HCBD) is a widely distributed environmental contaminant; however, information about its toxicity is limited. Most of the studies reported to date have dealt with acute toxicity (Leeuwangh et al., 1975; McConnell et al., 1975; Laska et al., 1976; Goldbach et al., 1976). Murzakaev (1963) determined the intraventricular LD50 values of 87,350 , and $90 \mathrm{mg} / \mathrm{kg}$ of HCBD in mice, rats, and guinea pigs, respectively.

\footnotetext{
${ }^{1}$ Present address: Department of Pathology and Hygiene, College of Veterinary Medicine, University of Illinois at Urbana-Champaign, Urbana, Illinois 61801 .

${ }^{2}$ Address correspondence to W. Seinen, Department of Veterinary Pathology, Bilstraat 172, Utrecht, The Netherlands.
}

Gradisky et al. (1975) reported LD50 values of 80 and 65 (oral) and 105 and 76 (ip) $\mathrm{mg} / \mathrm{kg}$ in mice, whereas in rats, values of 250 and 270 (oral) and 216 and 175 (ip), for males and females, respectively, were reported. Murzakaev $(1967 a, b)$ also reported that sublethal doses of HCBD had weak cumulative effects. Degenerative changes were found in the liver, kidneys, and myocardium, a decrease in serum SH concentration was noted, and the animals died with signs of central nervous system intoxication. Gradisky et al. (1975) found a marked allergic skin reaction to HCBD in guinea pigs. In subacute inhalation toxicity studies in rats, Cage (1970) found respiratory effects and degeneration of proximal renal tubules and adrenal cortex at 
doses of 250,100 , and $25 \mathrm{ppm}$. Females were more affected than males.

Poteryaeva (1966) reported the death of newborn rats from mothers given a single sc dose of $20 \mathrm{mg}$ of $\mathrm{HCBD} / \mathrm{kg} 3$ months previously. However, in Japanese quail (Coturnix coturnix japanica), no effect of HCBD on reproduction could be established (Schwetz et al., 1974).

Kociba et al. (1977) recently reported renal adenomas and adenocarcinomas in rats given doses of $20 \mathrm{mg} / \mathrm{kg} /$ day for 2 years; renal toxicity was noted at doses of $2 \mathrm{mg} / \mathrm{kg}$ or more.

The purpose of this report is to describe the results of range-finding, reproduction, and subacute (13-week) toxicity experiments with HCBD.

\section{METHODS}

Hexachloro-(1,3)-butadiene ${ }^{3}$ was thoroughly mixed with a commercial ration and fed at various levels or dissolved in arachid oil and given by gavage as $1 \mathrm{ml}$ of oil solution $/ \mathrm{kg}$.

Specific pathogen-free Wistar-derived ( $\mathrm{Cpb}$ WU/WI) rats ${ }^{5}$ were distributed among groups of six or 10 per group in plastic or wire-mesh cages, respectively, and housed at $23 \pm 2^{\circ} \mathrm{C}$ room temperature, approximately $55 \%$ relative humidity, and a light cycle of $07: 00-18: 00$. Food and tap water were provided ad libitum.

Range-finding study. Groups of 24 male and female weanling rats each were randomly distributed among four groups and fed diets containing $0,50,150$, and 450 ppm of HCBD for 2 weeks. Food samples were assayed for HCBD by gas chromatography on Days 0 , 7 , and 14 (Table 1).

The rats were weighed on Day 0 and terminally on Day 14. Food consumption was recorded during the experiment. At necropsy, the liver and kidneys were weighed, fixed in neutral buffered $10 \%$ formalin, embedded in Paraplast, ${ }^{6}$ sectioned at $5 \mu \mathrm{m}$, and stained

${ }^{3}$ Obtained from Fluka, Buchs, Switzerland. Purity $>95 \%$.

${ }^{4}$ Muracon 1, Trouw \& Co., Putten, The Netherlands.

s Obtained from the Central Institute for Breeding of Laboratory Animals, TNO, Zeist, The Netherlands.

- Paraplast plus, Sherwood Medical Industries, St. Louis, Missouri, U.S.A.
TABLE 1

Dietary CONCENTRATION OF HCBD ImMediately after Preparation and after Storage in Closed Containers at $4^{\circ} \mathrm{C}$ for 1 and 2 Weeks

\begin{tabular}{ccccc}
\hline & \multicolumn{4}{c}{ Dietary level of HCBD (ppm) } \\
\cline { 2 - 5 } Day of & \multicolumn{4}{c}{ Initial concentration } \\
\cline { 2 - 5 } analysis & 0 & 50 & 150 & 450 \\
\hline 0 & 0 & 73 & 182 & 447 \\
7 & 0 & 54 & 175 & 423 \\
0 & 14 & 55 & 148 & 306 \\
\hline
\end{tabular}

with hematoxylin and eosin. Kidney sections were also stained with PAS.

Reproduction study. Eighteen females and six male rats 10 weeks of age were used. The females were randomly distributed among three groups and fed diets containing 0,150 , or $1500 \mathrm{ppm}$ of HCBD. At weekly intervals, new diets were prepared and stored in closed containers at $4^{\circ} \mathrm{C}$. At the beginning of the fourth week, two untreated male rats were placed with the females for 3 weeks, after which the females were individually housed. Upon parturition, the litters were weighed, and the number of pups was counted and randomly reduced to eight per litter. The number and weight of offspring were recorded on Days 10 and 20 after birth.

At Week 18, the rats were killed by decapitation, and a necropsy was performed. The weights of heart, liver, kidneys, spleen, brain, adrenals, thymus and thyroids were recorded. Samples of these organs and lung, pancreas, digestive tract (six levels), urinary bladder, axillary and mesenteric lymph nodes, trachea, spinal cord, and femoral nerve were processed for histopathological examination. Sections were stained with hematoxylin and eosin, and kidney sections were also stained with PAS. The femoral nerve was fixed in formalin for $48 \mathrm{hr}$, treated for 30 min with osmium tetroxide, and teased in single fibers. The uterus was treated with a $10 \%$ ammonium sulfate solution in water for staining of the implantation sites.

Examinations for porphyrins were made by gross examination under ultraviolet light and by fluorescence microscopy ${ }^{7}$ of unstained cryostat sections of liver and kidneys.

Subacute study. Sixty male and 60 female weanling rats were randomly distributed among six groups and given $0,0.4,1,2.5,6.3$, and $15.6 \mathrm{mg}$ of $\mathrm{HCBD} / \mathrm{kg} /$ day by gavage for 18 weeks. Individual body weights and food consumption were recorded twice weekly.

${ }^{7}$ Carl Zeiss, Oberkochen, Germany. Exciting filters, BG 38/25 and BG 12/4; barrier filters, 53 and 33; Osram pressure lamp $\mathrm{HBO}, 200 \mathrm{~W}$. 
Blood samples were collected after 8 weeks and terminally from six animals per group. Of the former, hemoglobin, hematocrit, erythrocyte, and total and differential leukocyte counts were determined. Of the latter, total protein, albumin, $\alpha-, \beta-, y$-globulin, blood urea nitrogen, glutamic-oxaloacetic transaminase (GOT), alkaline phosphatase (AP), and $\gamma$-glutamyltranspeptidase $(\gamma-\mathrm{GT})$ were determined, all by conventional methods.

After 10 weeks, urine samples were collected from six animals of each group during the 2 nd-6th and 7 th-21st hour deprivation period of food and water, and tests were made for glucose, protein, hemoglobin, ketones, and $\mathrm{pH}$. To test the concentration ability of the kidneys, the total urine production of each rat, as well as the osmolarity of individual urine samples, were determined with an osmometer. ${ }^{8}$

After 13 weeks, the animals wese killed by decapitation, and a necropsy was performed. The weights of heart, liver, kidneys, spleen, brain, adrenals, thymus, thyroids, and gonads were recorded. Samples of organs listed in the reproduction section above, as well as the prostate, skeletal muscle, aorta, Harder's gland, skin, and sternum with bone marrow were fixed in formalin. These tissues from the control and highest dose groups were processed for histopathological examination, along with selected organs of all intermediate groups.

Gross chromatographic residue analyses were performed on kidney samples from females at all doses and on fat and liver samples from females at the highest dose. The tissues were homogenized, dried with anhydrous sodium sulfate, and extracted with acetone. HCBD was partitioned into hexane and determined on a Tracor $550^{\circ}$ gas chromatograph equipped with a ${ }^{63} \mathrm{Ni}$ electron capture detector. A Pyrex $1.80-\mathrm{m}$ column packed with $10 \%$ Bentone 34 on Anakrom ABS (90/100) was kept at $130^{\circ} \mathrm{C} ; \mathrm{N}_{2}$ gas flowrate, 60 $\mathrm{ml} / \mathrm{min}$; injector temperature, $300^{\circ} \mathrm{C}$. The recoveries of added HCBD were $51.8 \%$ for kidney tissue, $30.5 \%$ for liver tissue, and $40.1 \%$ for fat tissue.

Statistics. Data from the range-finding and reproduction study were analyzed for significance of differences by Student's $t$ test (de Jonge, 1960). For the 13-week data, a one-factor variance analysis test according to Scheffé (1967) was applied.

\section{RESULTS}

\section{Range-Finding Study}

Both male and female rats fed HCBD diets for 14 days showed significant inhibition of growth which was generally dose-related

${ }^{8}$ Halbmicro osmometer, Knauer \& Co., Berlin, Germany.

${ }^{9}$ Tracor Inc., Austin, Texas.
(Table 2). The decrease in weight gain was associated with a dose-related decrease in food conversion efficiency (gram of growth/ gram of food). Although total food consumed by HCBD-fed animals was decreased, when expressed per gram of body weight, food consumption was decreased only at the highest dose.

Relative kidney weights (Table 2) were increased in both males and females at the two highest doses. Histopathologic changes were found in the kidneys of all animals fed IICBD, characterized by degeneration of tubular epithelial cells which occurred in a dose-related manner, especially in the straight limbs of the proximal tubules located in the outer zone of the medulla. No changes were found in other organs examined.

\section{Reproduction Study}

The fertility, number, and weights of litters born and raised, and the resorption quotient (number of implantation sites per number of pups), are given in Table 3. Apparently no conception occurred in the 1500-ppm dosage group. The animals lost weight progressively and displayed weakness of the hind legs and unsteady gait. Incoordination developing into ataxia without paralysis was seen during Week 6. After Week 8, the condition of the animals rapidly deteriorated. At the $150-\mathrm{ppm}$ dose level, five of six females were fertile, and although one animal delivered only three pups, the mean litter size of this group was comparable to that of the control group. However, birth weights of the pups were significantly lower than those of controls $(p<0.05)$. Growth was retarded, and consequently, significant differences in body weights were found at weaning age. In both the control and 150-ppm groups, the resorption quotient was low. Grossly observable malformations were not seen.

Since conception apparently did not occur in the 1500 -ppm group, and considering the condition of the animals, necropsies were performed during Week 10. Grossly, these animals displayed large pale kidneys, and 


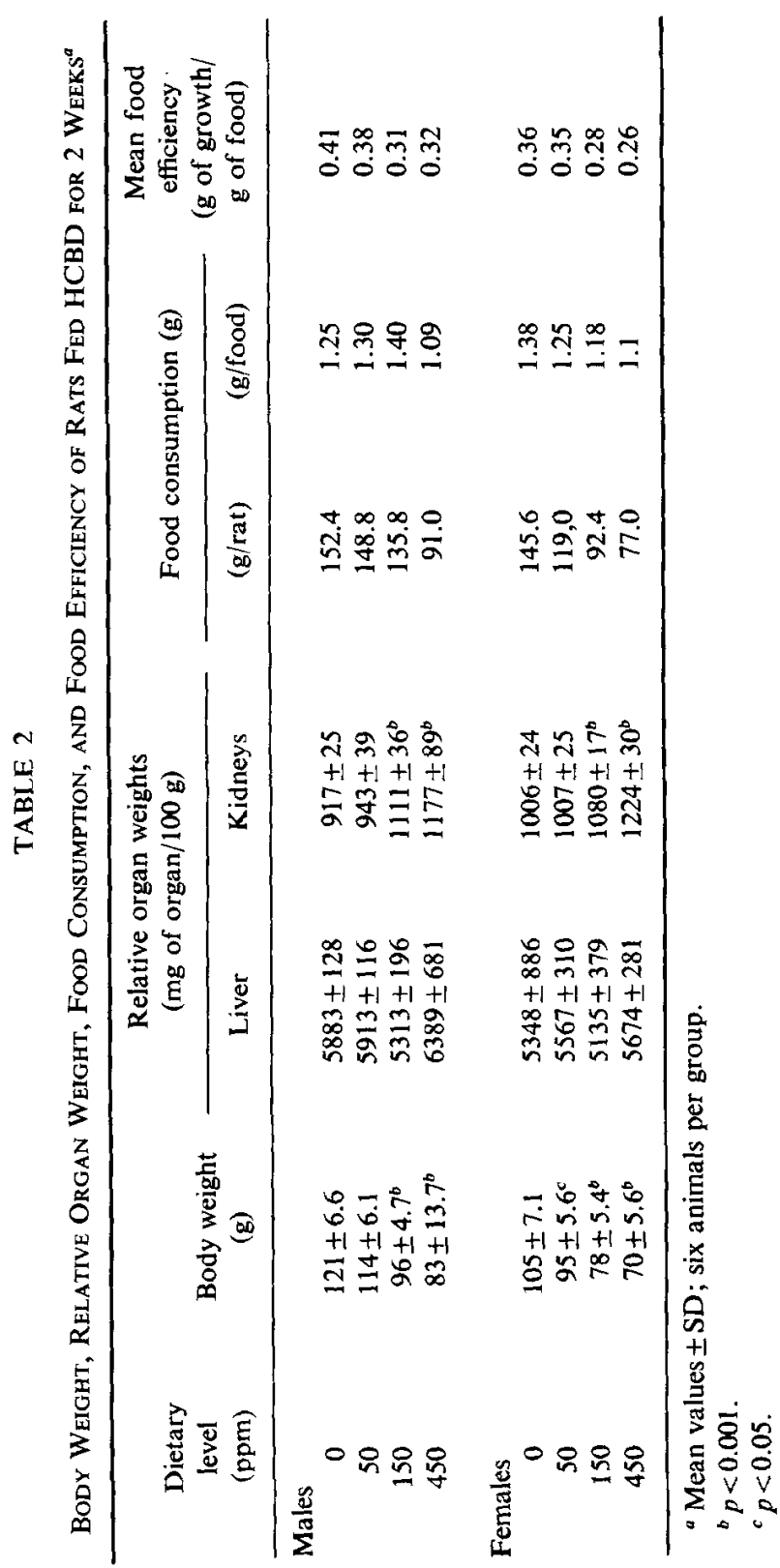




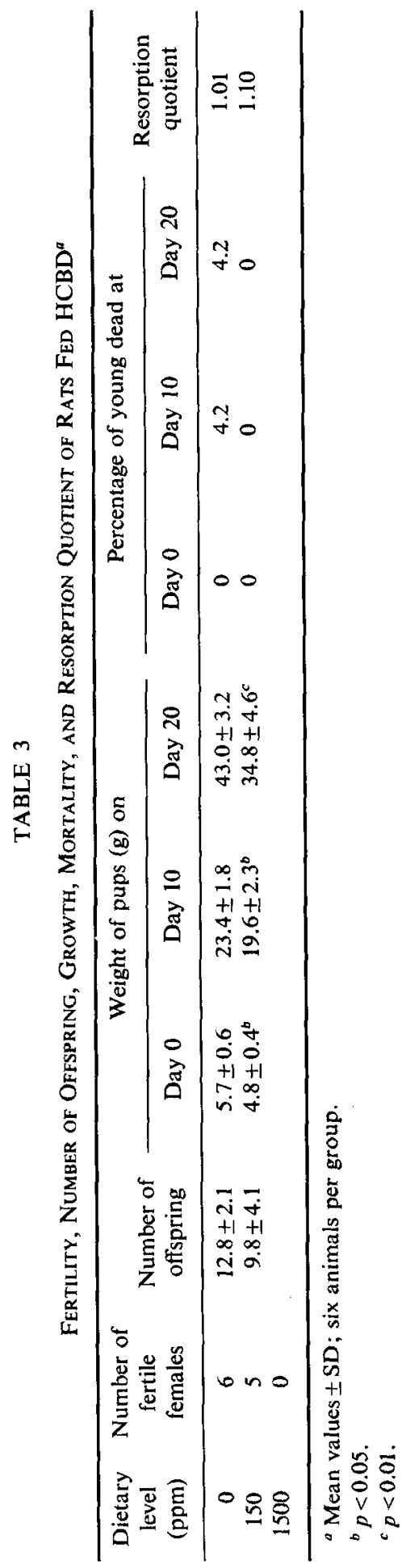


histologically, extensive tubular degeneration was found. In the liver, slight proliferation of bile duct epithelial cells was apparent. Teased femoral nerves showed fragmentation and demyelinization of single fibers (Fig. 1), which may explain the motor disturbances noted in rats. Brain lesions were not apparent, little follicular activity was observed in the ovaries, and no implantation sites were found in the uterus.

Animals of the 150-ppm of HCBD and control group were killed during Week 18. Body weights were significantly lower in the 150-ppm group (controls, $231 \pm 24 \mathrm{~g}$; 150ppm group, $196 \pm 23 \mathrm{~g} ; p<0.05$ ). Relative kidney weights were markedly increased (controls, $652 \pm 62 \mathrm{mg} / 100 \mathrm{~g}$ body weight; $150 \mathrm{ppm}$ group, $798 \pm 55 \mathrm{mg} / 100 \mathrm{~g}$ body weight; $p<0.01$ ). Other organ weights were not affected. At the 150-ppm level, histopathological changes attributed to treatment were observed only in the kidney which included hypercellularity of epithelial lining cells and hydropic degeneration and necrosis of individual cells in the straight limbs of the proximal tubules. Porphyria was not observed.

\section{Thirteen-Week Study}

Except for a dose-related decrease in body weights of animals given 6.3 and $15.6 \mathrm{mg}$ of $\mathrm{HCBD} / \mathrm{kg} /$ day (Fig. 2), general health of the rats remained unaffected. At the highest dose, weight gain of animals of both sexes was less than $60 \%$ of the controls (Table 4). At the $6.3-\mathrm{mg} / \mathrm{kg}$ dose, growth retardation was more pronounced in females than in males (i.e., 30 and $13 \%$, respectively), and was associated with a dose-related decrease in food consumption (Table 4). Food efficiency was also reduced in both sexes at the highest dose and in females during the first three weeks at the $6.3-\mathrm{mg} / \mathrm{kg}$ dose.

\section{Clinical Chemistry}

Blood analysis data were similar for all groups.

During a 21-hr deprivation period, females

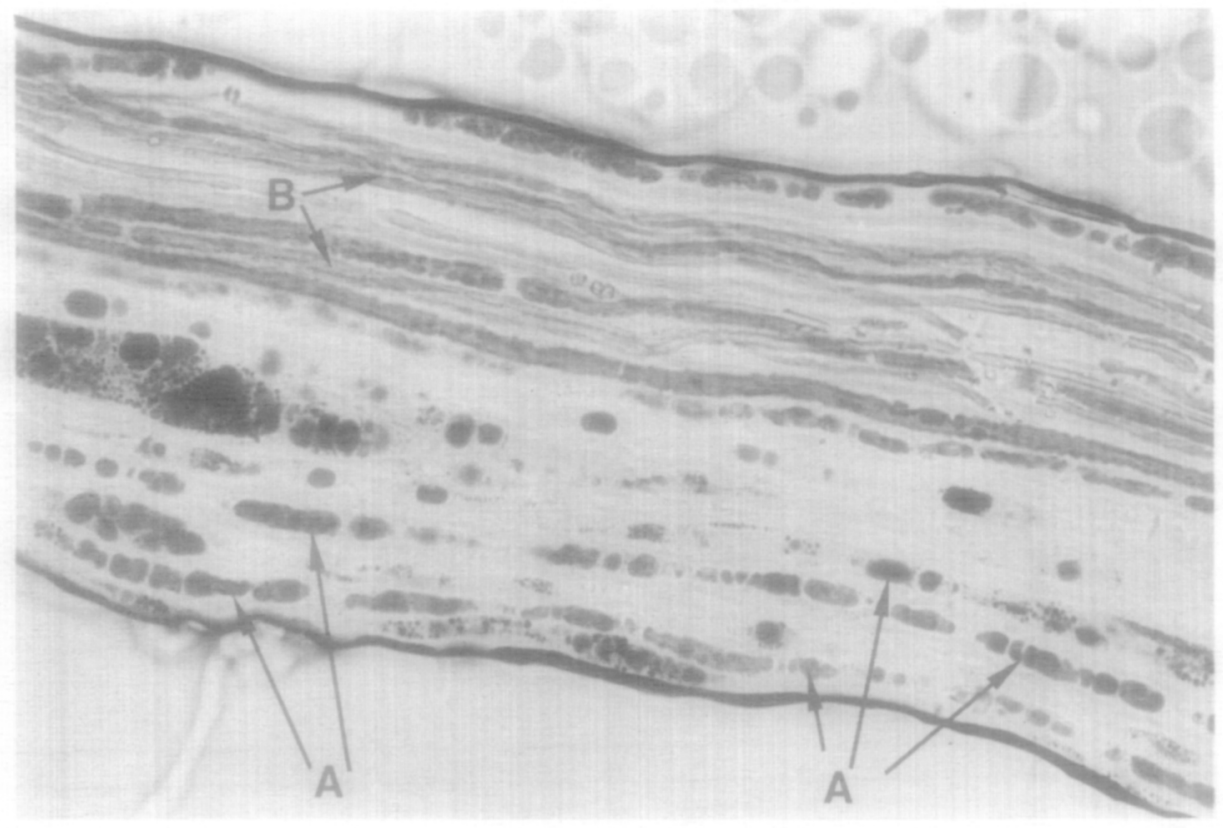

FIG. 1. Teased femoral nerve fibers. Osmium- tetroxide. $\times 250$. Note the disintegration of myelin sheaths; note fractionated globules of various sizes (arrow A) and normal myelin sheaths (arrow B). 


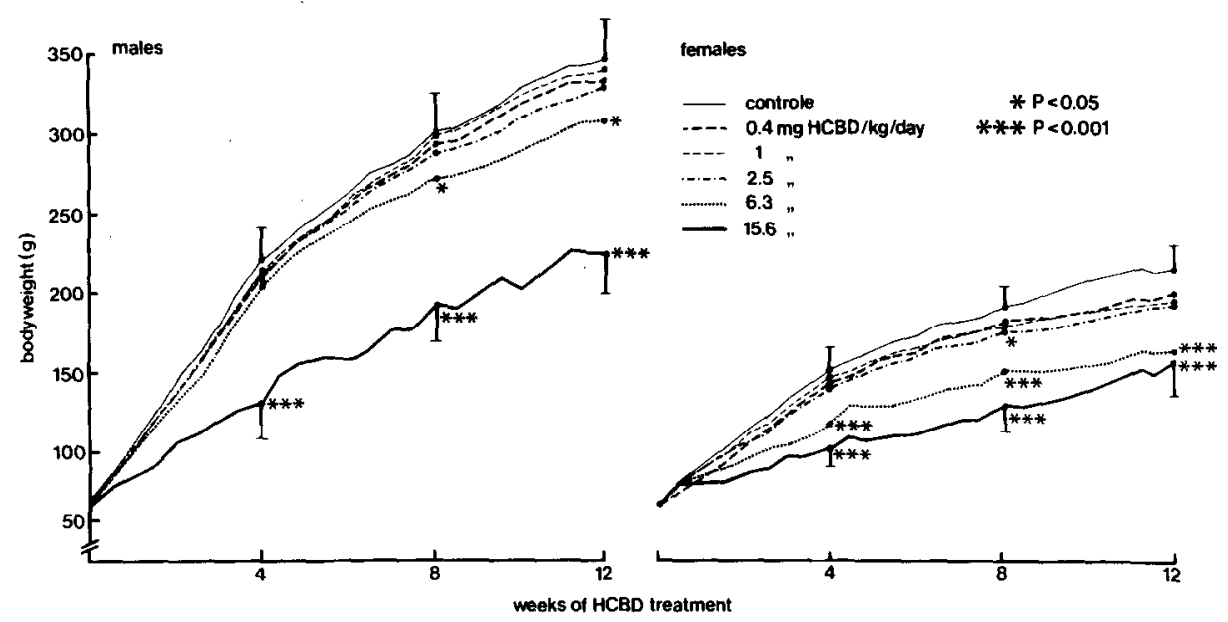

FIG. 2. Body weights of male and female rats given $0,0.4,1,2.5,6.3$, and $15.6 \mathrm{mg}$ of $\mathrm{HCBD} / \mathrm{kg} / \mathrm{day}$ by oral gavage for 12 weeks.

at the two highest doses produced significantly more urine than did females of the control group (Table 5). Urine osmolarity, a more sensitive criterion of impaired kidney concentration ability, was decreased in both sexes at the highest dose. In females, concentration ability was decreased in a doserelated fashion from the $2.5-\mathrm{mg} / \mathrm{kg}$ level. Otherwise, urine analysis data were similar for the various groups.

\section{Organ Weights}

Body weights and relative organ weights are given in Table 6 . The relative kidney weights were dose-related and significantly $(p<0.001)$ increased in both sexes at the $6.3-$ and $15.6-\mathrm{mg} / \mathrm{kg}$ doses. At lower doses, relative kidney weights were slightly increased, although not always significantly higher than the control values. Relative liver weights in the two highest dose groups of the male rats were markedly increased $p<0.001$ ), whereas in females a slight increase of relative liver weight was found only at the $15.6-\mathrm{mg} / \mathrm{kg}$ dose $(p<0.05)$. Relative spleen weights were significantly increased in males given $15.6 \mathrm{mg} /$ $\mathrm{kg}(p<0.05)$ and in females at the 6.3$(p<0.05)$ and $15.6-\mathrm{mg} / \mathrm{kg}(p<0.01)$ dose levels. Relative brain and testicle weights showed an inverse relationship with body weight which is known to be a common recurrence. Other relative organ weight data were similar for the various groups.

\section{Pathological Changes}

Gross organ changes were not observed at necropsy. Microscopically, treatment-related pathological changes were noted in the kidneys and liver.

In females at the highest dose, kidney changes were observed both in the convoluted and straight limbs of the proximal tubules. Epithelial cells of the proximal tubules showed large hyperchromatic nuclei. Hypercellularity of the epithelial lining was the most prominant feature in the straight segment of the proximal tubules (Fig. 3). In comparison with the controls (Fig. 2), these epithelial cells were small, morc basophilic, and finely vacuolated, especially at the base (Fig. 3). The nuclei were relatively large, often hyperchromatic with prominent nucleoli. Focally, necrotic cells were observed, and nuclear detritus was found in the lumen (Fig. 3). The brush border of the epithelial lining was somewhat thinner or absent. In two animals of this group, calcified casts were found in Henle's loops and collecting ductules. Comparable renal changes were found in females at the $6.3-\mathrm{mg} / \mathrm{kg}$ dose 
HARLEMAN AND SEINEN

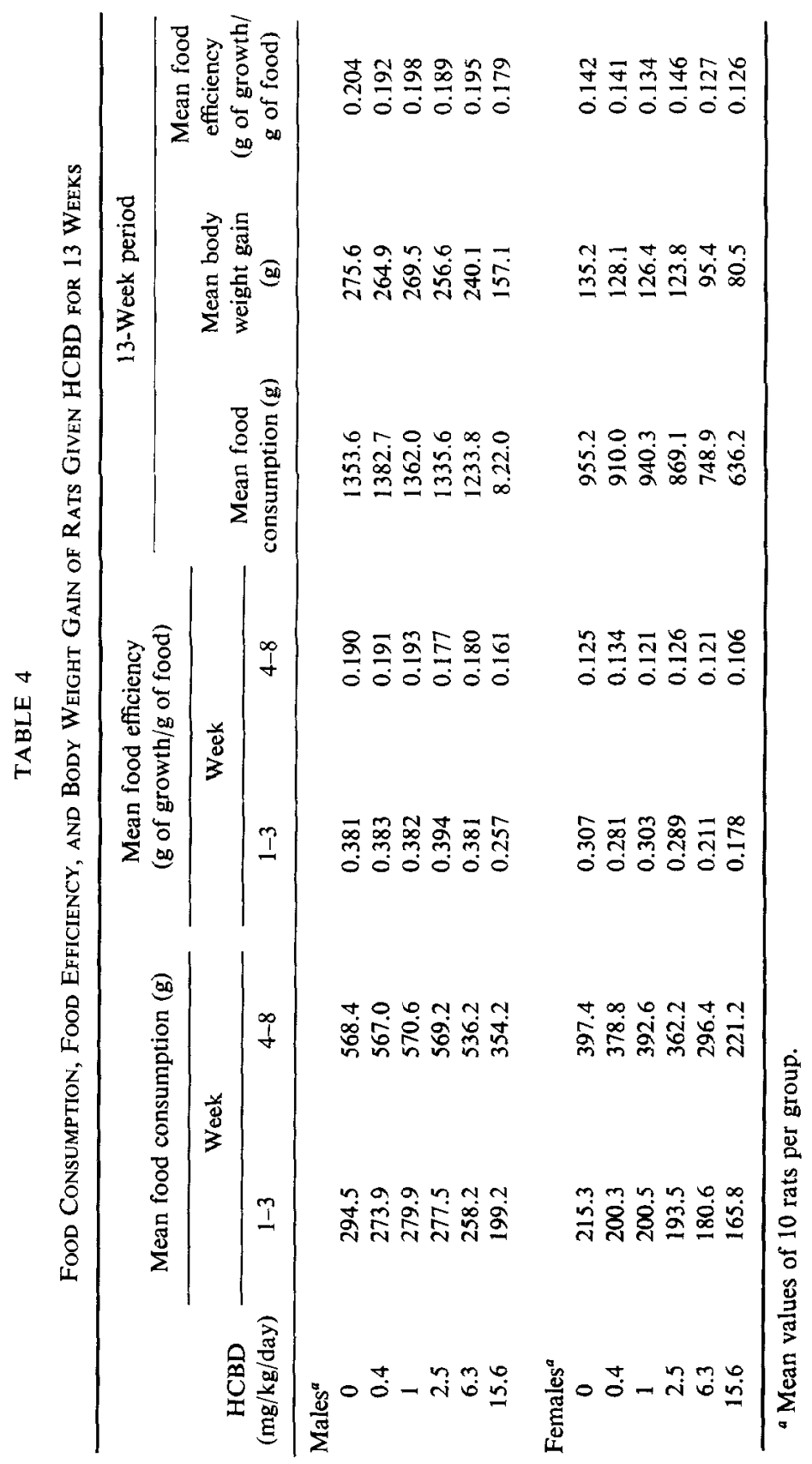


TABLE 5

Total Production and Osmolarity of Rat Urine Collected during a 21-hr Period of Food AND WATER Deprivation ${ }^{a}$

\begin{tabular}{cccccc}
\hline $\begin{array}{c}\text { Dose } \\
(\mathrm{mg} \text { of } \\
\mathrm{HCBD} /\end{array}$ & \multicolumn{2}{c}{$\begin{array}{c}\text { Urine osmolarity } \\
(\mathrm{mosmol})^{b}\end{array}$} & & \multicolumn{2}{c}{$\begin{array}{c}\text { Total urine } \\
\text { production }(\mathrm{ml})\end{array}$} \\
\cline { 6 - 7 } \cline { 5 - 6 } $\mathrm{kg} /$ day) & Females & Males & & Females & Males \\
\hline 0 & $2100 \pm 383$ & $1776 \pm 292$ & & $4.2 \pm 1.1$ & $5.9 \pm 1.7$ \\
0.4 & $1808 \pm 435$ & $1697 \pm 302$ & & $4.2 \pm 1.6$ & $6.1 \pm 1.1$ \\
1 & $2171 \pm 329$ & $1672 \pm 136$ & & $3.2 \pm 0.8$ & $5.6 \pm 0.7$ \\
2.5 & $1448 \pm 247^{c}$ & $1891 \pm 261$ & & $5.8 \pm 1.8$ & $5.5 \pm 1.0$ \\
6.3 & $1215 \pm 169^{d}$ & $1659 \pm 231$ & & $6.3 \pm 0.9^{c}$ & $5.2 \pm 0.7$ \\
15.6 & $1207 \pm 300^{c}$ & $1102 \pm 220^{c}$ & & $5.9 \pm 1.0^{\text {e }}$ & $6.9 \pm 2.9$ \\
\hline
\end{tabular}

a Mean values $\pm \mathrm{SD}$; six animals per group.

${ }^{b}$ The osmolarity data are given for the 7 - and $21-\mathrm{hr}$ urine samples, since in this period the osmolarity war more reduced by HCBD than in the 2- and 6-hr collection periods.

${ }^{c} p<0.01$.

$d p<0.001$.

${ }^{e} p<0.05$.

group; however, they were present to a lesser degree and restricted to the straight parts of the proximal tubules. Increased cellularity of epithelial lining cells was also noted. These cells stained more basophilic, were finely vacuolated, and contained relatively large nuclei. However, the brush border was mostly unchanged or only focally thinner, and only a few necrotic cells were present in the lumens. Only minor pathological changes were found in females of the $2.5-\mathrm{mg} / \mathrm{kg}$ group, although epithelial cells of the straight parts of the proximal tubules contained enlarged hyperchromatic nuclei.

In males, kidney changes were less pronounced than in females. At the highest dose, the alterations were comparable with females at $6.3 \mathrm{mg} / \mathrm{kg}$ (Figs. 4 and 5); changes in males at $6.3 \mathrm{mg} / \mathrm{kg}$ were the same as those in females at $2.5 \mathrm{mg} / \mathrm{kg}$.

Liver changes occurred only in males, characterized by increased basophilic, flocky granulation, which was most prominent in zone I of the liver acinus (Rappaport et al., 1954), and was found in the highest dose group and in two males at $6.3 \mathrm{mg} / \mathrm{kg}$. These changes gave rise to a striated lobular pattern at low magnification.

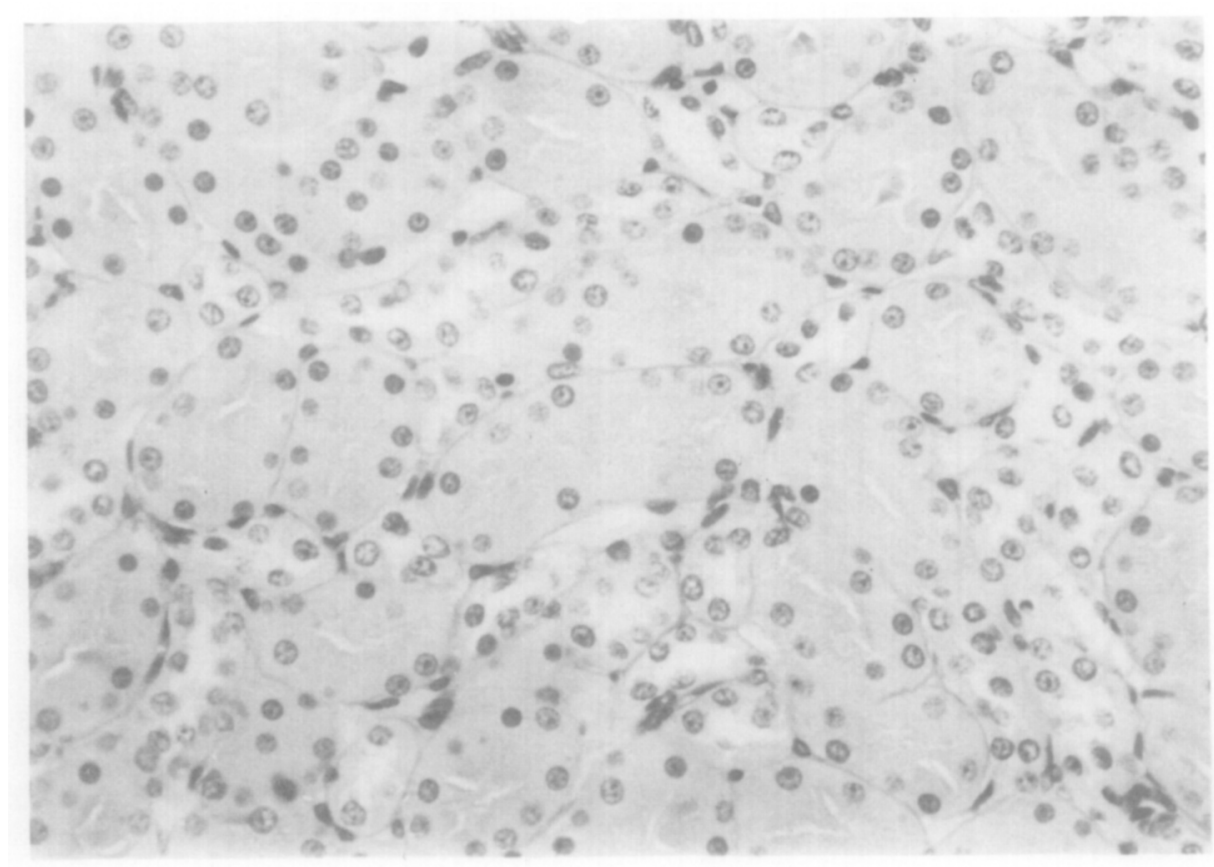

Fig. 3. Kidney, Outer zone of the medulla of a control animal. PAS staining. $\times 100$. 


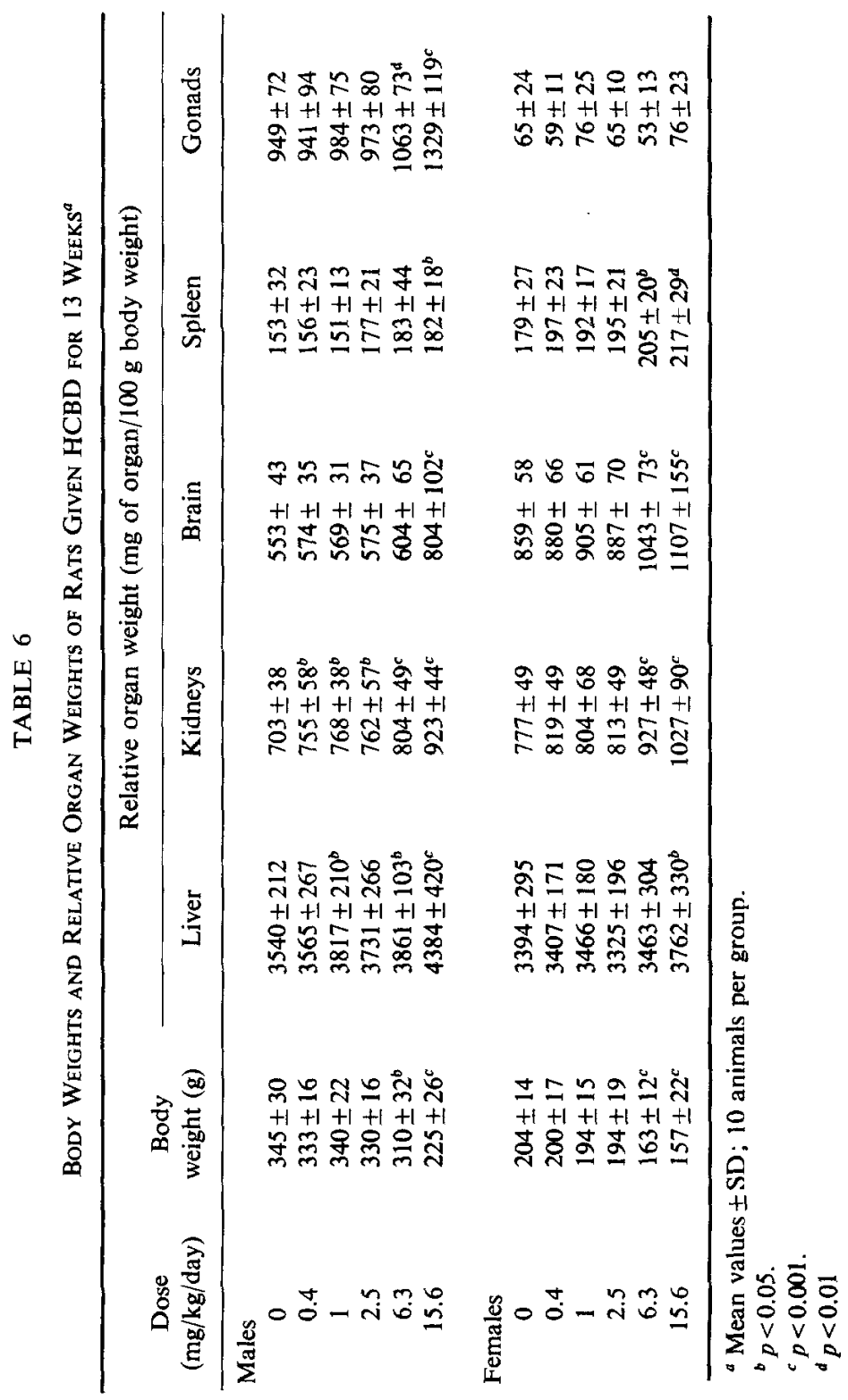




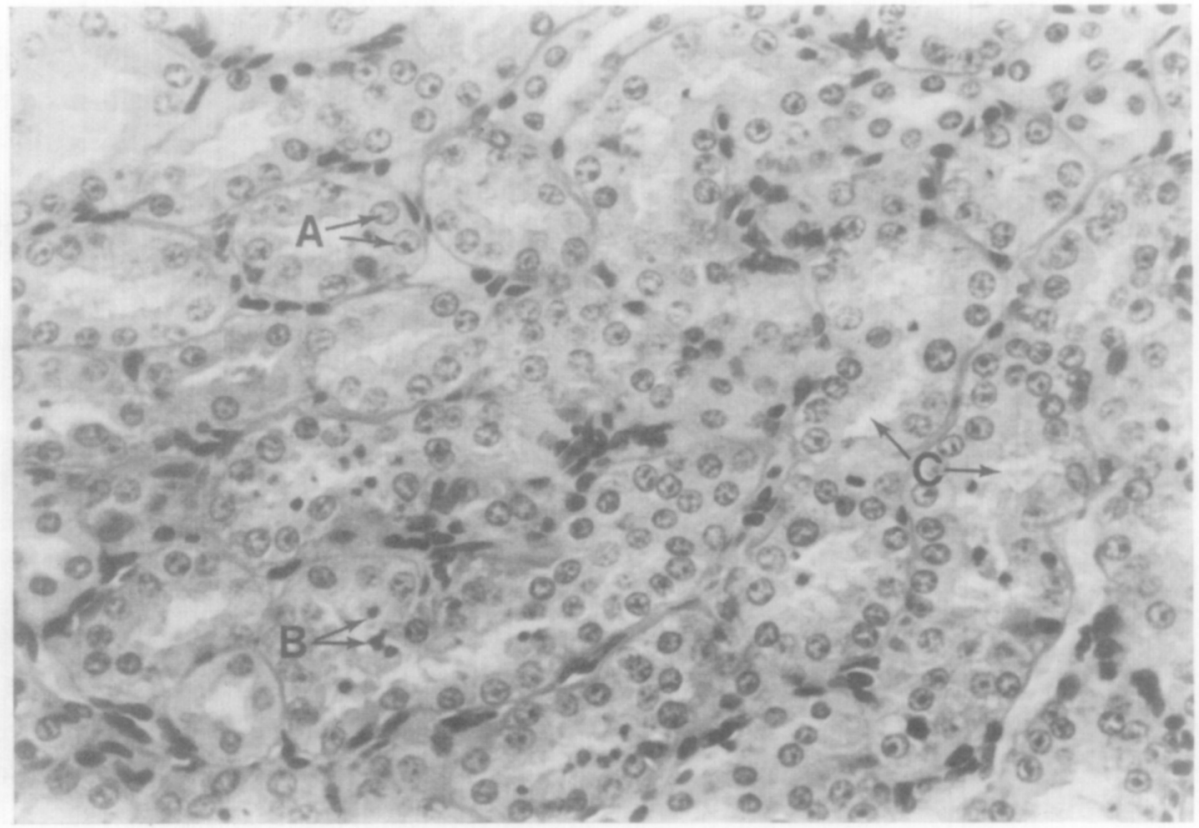

Fig. 4. Kidney. Outer zone of medulia of a female rat given $15.6 \mathrm{mg} / \mathrm{kg}$. PAS staining. $\times 100$. Note hypercellularity of the straight part of the proximal tubules and swollen, hyperchromatic nuclei (arrow A), necrotic cells (arrow B), and diminished brush borders (arrow C).

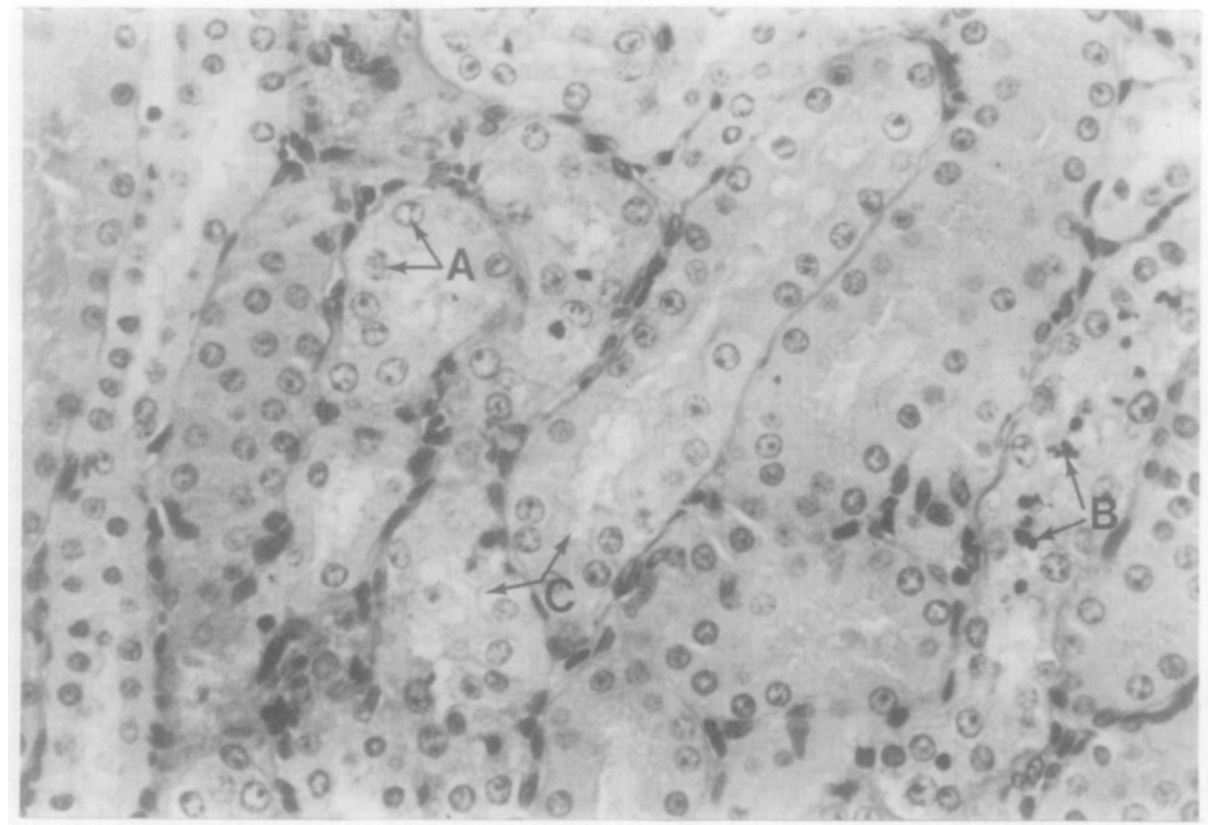

FIG. 5. Kidney. Outer zone of the medulla of a male rat given $15.6 \mathrm{mg} / \mathrm{kg}$. PAS staining. $\times 100$. Note swollen hyperchromatic nuclei (arrow A), necrotic cells (arrow B), and the thin or absent brush borders (arrow C) of the rectal part of the proximal tubules. 
TABLE 7

Residues of HCBD in Liver, Adipose Tissue, AND Kidnfy of Female Rats Given HCBD for 13 WEEKS $^{a}$

\begin{tabular}{cccc}
\hline $\begin{array}{c}\text { Dose } \\
(\mathrm{mg} / \mathrm{kg} / \text { day })\end{array}$ & $\begin{array}{c}\text { Liver } \\
(\mathrm{ppm})\end{array}$ & $\begin{array}{c}\text { Adipose } \\
\text { tissue } \\
(\mathrm{ppm})\end{array}$ & $\begin{array}{c}\text { Kidney } \\
(\mathrm{ppm})\end{array}$ \\
\hline 0 & $\mathrm{na}^{\mathrm{b}}$ & na & $0.21 \pm 0.11$ \\
0.4 & $\mathrm{na}$ & na & $0.34 \pm 0.07$ \\
1 & na & na & $0.40 \pm 0.05$ \\
2.5 & na & na & $0.79 \pm 0.30$ \\
6.3 & na & na & $0.96 \pm 0.14$ \\
15.6 & $0.51 \pm 0.17$ & $100.6 \pm 16.8$ & $2.03 \pm 0.58$ \\
\hline
\end{tabular}

${ }^{a}$ Mean values $\pm \mathrm{SD}$.

${ }^{b}$ na $=$ not analyzed.

The results of gas chromatographicanalyses are given in Table 7. HCBD did not appear to accumulate in the liver or kidneys, although a slight accumulation was found in adipose tissue.

\section{DISCUSSION}

In the present study, body weights were decreased after only 2 weeks at 150 or $450 \mathrm{ppm}$, not all of which could be attributed to reduced palatability of the diet, since growth retardation also occurred in animals given 6.3 and $15.6 \mathrm{mg}$ of $\mathrm{HCBD} / \mathrm{kg}$ by gavage.

The most prominent toxicological feature of HCBD was nephrotoxicity. Decreased urine concentrating ability was found in females at low dosages $(2.5 \mathrm{mg} / \mathrm{kg})$ without histologic evidence of renal injury. At higher doses, extensive tubular degeneration was noted in animals of both sexes, especially in the straight segments of proximal tubules. Degeneration and necrosis of individual epithelial cells occurred, along with increased cellularity of the epithelial lining. This alteration resembled regenerating epithelium, such as that reported in the proximal tubules 7-10 days after a single ip injection of $1.5 \mathrm{mg}$ of $\mathrm{HgCl}_{2} / \mathrm{kg}$ (Cuppage and Tate, 1967), and is, therefore, considered a simple repair process.
Increased proliferation of tubular epithelial cells occurred in rat kidneys after a single injection of $40 \mathrm{mg}$ of lead acetate $/ \mathrm{kg}$, but without morphologically discernible cell damage (Choie and Richter, 1972a). After long-term lead exposure, focal tubular hyperplasia occurs (Choie and Richter, 1972b) and renal tumors develop (Boyland et al., 1962; Van Esch et al., 1962; Van Esch and Kroes, 1969). In the case of HCBD, tubular hyperplasia seems related to an exuberant regenerative activity; however, it probably should be considered a preneoplastic change, since Kociba et al. (1977) recently reported the occurrence of renal adenomas and adenocarcinomas in rats maintained for 2 years on diets supplying $20 \mathrm{mg} / \mathrm{kg} /$ day of HCBD.

Kidney lesions were more pronounced in females than in males and occurred at doses as low as 2.5 and $6.3 \mathrm{mg} / \mathrm{kg}$, respectively. Also, the inability to concentrate urine was more apparent in females, whereas liver changes were more marked in males. At the two high doses, liver weights were markedly increased in males, whereas in females, the liver was slightly enlarged only at the highest dose. Morphologically, liver enlargement in the males was associated with a flocky basophilic granulation of the cytoplasm, suggesting an increase of granular endoplasmic reticulum. Evidence for an obvious increase of smooth endoplasmic reticulum was not observed.

Since HCBD is readily absorbed from the intestinal tract (Gradisky et al., 1975) and accumulates only marginally in adipose tissue, it should be readily cleared from the body. It is probably metabolized to a glutathione conjugate, although direct evidence is lacking. Murzakaev (1967a) found a decreased serum SH-group concentration in guinea pigs and rats fed $7 \mathrm{mg} / \mathrm{kg}$ for 6 months. Moreover, the acute toxicity of HCBD was $40-60 \%$ less in animals simultaneously dosed with $100 \mathrm{mg} / \mathrm{kg}$ of unithiol (Murzakaev, 1976b). If glutathione conjugation is a major pathway of HCBD detoxification, the differences observed may be related to 
sex differences in glutathione $S$-transferases as described by Kaplowitz et al. (1975) and Clifton et al. (1975) in hepatic and kidney cytosol of rats after treatment with phenobarbital, 3-methylcholanthene, and 3,4-benzopyrene.

Neurotoxicity of HCBD was observed only at high doses. Animals fed $1500 \mathrm{ppm}$ showed incoordination. Microscopically, demyelination and fragmentation of femoral nerve fibers were observed. In acute experiments, Murzakaev (1967a) and Gradisky et al. (1975) also noted incoordination and paralysis.

Effects on reproduction observed at the 1500-ppm level are considered an indirect effect of HCBD, probably related to the poor physical condition of the animals. At 150 ppm, reproduction was not affected, except for a decrease in litter weight. In Japanese quail, Schwetz et al. (1974) did not find any reproduction disturbancies. These results are at variance with those of Poteryaeva (1966) who reported death of offspring from mothers given a single sc dose of $20 \mathrm{mg} / \mathrm{kg}$.

The carcinogenicity of HCBD makes this generally distributed substance a risky environmental contaminant. As HCBD is formed during perchloroethylene production, industrial exposure will need further consideration. Research is also needed to determine whether HCBD on its own, or its metabolites, is responsible for the tissue lesions and carcinogenicity as reported for other chlorinated aliphatic hydrocarbons (Bonse and Henschler, 1976).

From this study, it is concluded that the main toxic action of HCBD in the rat is on the kidneys. It also induces hepatic changes and neurotoxicity at high levels. No effect levels in a 13-week study in rats was $1 \mathrm{mg} / \mathrm{kg} /$ day in females and $2.5 \mathrm{mg} / \mathrm{kg} /$ day in males.

\section{ACKNOWLEDGMENTS}

The authors thank Dr. A. J. H. Schotman, Department of Internal Medicine, for the determination of serum enzyme activities and Dr. H. Könemann, Department of Pharmacology-Toxicology for the residue analysis.

\section{REFERENCES}

Bonse, G., And Henschler, D. (1976). Chemical reactivity, biotransformation and toxicity of polychlorinated aliphatic compounds. CRC Crit. Rev. Toxicol. 4, 395-409.

Boyland, E., Dukes, C. E., Grover, P. L., ANd Mitchley, B. C. V. (1962). The induction of renal tumors by feeding lead acetate to rats. Brit. $J$. Cancer 16, 283-288.

CAGE, J. C. (1970). The subacute inhalation toxicity of 109 industrial chemicals. Brit. J. Ind. Med. 27, 1-18.

Choie, D. D., And Richter, G. W. (1972a). Cell proliferation in rat kidney induced by lead acetate and effects of uninephrectomy on the proliferation. Amer. J. Pathol. 66, 265-275.

Chole, D. D., AND Richter, G. W. (1972b). Cell proliferation in rat kidneys after prolonged treatment with lead. Amer. J. Pathol. 68, 359-367.

Clifton, G., Kaplowitz, N., Wallin, J. D., and Kuhlenkamp, J. (1975). Renal glutathion S-transferases: Drug induction and sex differences in the rat. Biochem. I. 150, 259-262.

Cuppage, F. E., And TATE, A. (1967). Repair of the nephron following injury with mercuric chloride. Amer. J. Pathol. 51, 405-417.

Goldbach, R. W., van Genderen, H., and LeeuWANGH, P. (1976). Hexachlorobutadiene residues in aquatic fauna surface water fed by the river $\mathrm{R}$ hine. Sci. Total. Environ. 6, 31-40.

Gradisky, D., Duprat, P., Magadur, J. L., AND FAyein, E. (1975). Étude toxicologique expérimentale de l'hexachlorobutadiène. Eur. J. Toxicol. 8, 180-187.

DE JONGE, H. (1960). Inleiding tot de medische statistiek. Verh. Ned. Inst. Prev. Geneesk. 48, XLVIII,

Kaplowitz, N., Kuhlenkamp, J., and Clifton, G. (1975). Drug induction of hepatic glutathion $S$ transferases in male and female rats. Biochem. $J$. 146, 351-356.

Kociba, R. J., Keyes, D. G., Jersey, G. C., Balland, J. J., DitTenber, D. A., Quast, J. F., W ADE, C. E., Humiston, C. G., AND Schwetz, B. A. (1977). Results of a two-year chronic toxicity study with hexachlorobutadiene (HCBD) in rats. Toxicol. Appl. Pharmacol. 41, 204.

Laska, A. L., Bartell, C. K., and Laseter, J. L. (1976). Distribution of hexachlorobutadiene in water, soil, and selected aquatic organisms along the lower Mississippi River, Louisiana. Bull. Environ. Contam. Toxicol. 15, 535-542.

LeeUWANGH, P., Bult, H., and Schneider, L. (1975). Toxicity of hexachlorobutadiene in aquatic organisms. In Sublethal Effects of Toxic Chemicals on Aquatic Animals (J. H. Koeman and J. J. T. W. A. Strik, eds.), pp. 167-176. 
McConnell, G., Ferguson, D. M., and Pearson, C. R. (1975). Chlorinated hydrocarbons and the environment. Endeavour 34, 13-18.

Murzakaev, F. G. (1963). Toxicity data for hexachlorobutadiene and its intermediates. Farmacol. Toksokol. 26, 750-753 [Abstracted in Chem. Abstr. 60, 13776 (1964)].

Murzakaev, F. G. (1967a). Action exterted by low hexachlorobutadiene doses on the activity of the central nervous system and morphological changes in animals so poisoned. Gig. Tr. Prof. Zabol. 11, 23-28 [Abstracted in Chem. Abstr. 67, 31040a (1967)].

Murzakaev, F. G. (1967b). Toxicological and hygienic characteristics of hexachlorobutadiene and its intermediate products. Dokl. Neftekhim. Sekts. Bashk. Resp. Pravl. Vses. Khim. Ova. im DJ Mendeleeva 2, 245-250 [Abstracted in Chem. Abstr. 67, 89280v (1967)].

Poteryaeva, G. E. (1966). Effect of hexachlorobutadiene on the offspring of albino rats. Gig.
Sanit. 31, 33-35 [Abstracted in Chem. Abstr. 65, $1281 \mathrm{f}(1966)]$.

RapPaport, A. M., Borowy, Z. J., LougheEd, W. M., AND LotTo, W. N. (1954). Subdisivion of hexagonal livel lobules into a structural and functional unit; role in hepatic physiology and pathology. Anat. Rec. 119, 11-34.

SCHeffé, H. (1967). The Analysis of Variance. John Wiley and Sons, New York.

Schwetz, B. A., Norris, J. M., Kociba, R. J., Keeler, P. A., Cornier, R. F., And Gehring, P. J. (1974). Reproduction study in Japanese quail fed hexachlorobutadiene for 90 days. Toxicol. Appl. Pharmacol. 30, 225-265.

VAN EsCH, G. J., AND KroEs, R. (1969). The induction of renal tumors by feeding basic lead acetate to mice and hamsters. Brit. J. Cancer 23, 765-771.

VAN EsCh, G. J., VAN Genderen, H., and VINK, H. H. (1962). The induction of renal tumors by feeding of basic lead acetate to rats. Brit. J. Cancer 16, 289-297. 